\title{
INTERACTION BETWEEN S-TYPE PYOCINS AND MICROCIN-II-LIKE BACTERIOCINS IN PSEUDOMONAS AERUGINOSA
}

\author{
O.B. Balko \\ Zabolotny Institute of Microbiology and Virology, NAS of Ukraine, \\ 154 Acad. Zabolotny Str., Kyiv, 03143, Ukraine \\ e-mail: oleksandrbalko@gmail.com
}

\begin{abstract}
According to our previous results, S-type bacteriocins of Pseudomonas aeruginosa are characterized by high activity against phytopathogenic Pseudomonas syringae strains. In addition to these pyocins producing strains are able to synthesize microcin-II-like bacteriocins. Presence of interaction between these two killer factors can determine methods of their use and activity increase of bacteriocins with antiphytopathogenic properties. The aim of the work was to test possibility of interaction between S-type pyocins and microcin-II-like bacteriocins of P. aeruginosa. Methods. The objects of the study were pyocins produced by 6 P. aeruginosa strains. Killer factors in composition of induced lysates were concentrated by $70 \%$ ammonium sulphate precipitation, dialyzed through dialysis membrane with molecular weight cut-off (MWCO) $3.5 \mathrm{kDa}$. Then ion-exchange chromatography with DEAE-cellulose, gel filtration with Sephadex G-75 and ultracentrifugation at $215.000 \mathrm{~g}$ for 1 and 4 hours were used for their separation. Protein concentration and antimicrobial activity were determined in obtained fractions. Visualization of proteins in active fraction composition was conducted by electrophoresis according to the Laemmli method. Results. Under ion-exchange chromatography with DEAE-cellulose application elution of bacteriocins available in lysate composition occurs simultaneously. The highest indices of activity and protein concentration were in the $4^{\text {th }}$ fraction, containing two protein bands with molecular weight near 58 and $9 \mathrm{kDa}$, which are typical for $S 5$ pyocin and microcin-II-like bacteriocins of P. aeruginosa. Further gel filtration of sampled fractions through Sephadex G-75 allowed to separate noted killer factors and obtaine purified fraction containing microcin-II-like pyocins only. Application of ultracentrifugation during 1 hour didn't precipitate studied bacteriocins, whereas during 4 hours - lead to their separation. At the same time a twofold increase of activity indices for S-type pyocins in precipitates and for microcin-IIlike killer factors - in supernatants were observed. However achieved concentration was characterized by short-term effect, since in 14 days activity of supernatants decreased by 4-16 times, and for precipitates by 80-640 times. Then revealed tendency for activity decrease continued. Conclusions. S-type pyocins and microcin-II-like bacteriocins of P. aeruginosa interact with each other, that ensures their stabilization and protects again destruction. Application of methods that cause separation of these killer factors is inexpedient, since it results into considerable decrease of bacteriocin activity indices.
\end{abstract}

Keywords: microcin-II-like bacteriocins, S-type pyocins, Pseudomonas aeruginosa, interaction.

It is well known that Pseudomonas aeruginosa strains are able to produce high-molecular bacteriocins and colicin-like bacteriocins - pyocins $[1,2]$. R- and F-type high-molecular killer factors include structures with molecular weight $1-10$ $\mathrm{MDa}$, which resemble to phage tails and realize their killer activity through pore formation in cell walls of sensitive bacteria [3, 4]. Colicin-like S-type pyocins are characterized by molecular weight of 30-100 kDa and cause microorganism death by different mechanisms $[5,6]$. Properties of these substances, peculiarities of their induction and killer action so as ability of some strains to produce them are described $[7,8]$. Influence of induction conditions can lead to simultaneous synthesis of both types of bacteriocins by producer cultures $[9,10]$.

Previously we showed that $P$. aeruginosa strains can produce pyocins of another one type low-molecular microcin-II-like killer factors with molecular weight near $9 \mathrm{kDa}$ [11]. Bacteriocins with a molecular weight below $10 \mathrm{kDa}$ are produced by Escherichia coli (microcins). They are divided into two classes: class I microcins are small peptides $(<5 \mathrm{kDa})$ and class II microcins are larger $(5$ to $10 \mathrm{kDa})[12,13]$. However, the 
presence of such bacteriocins in Pseudomonas syringae has been shown only recently [14] and Ghequire and De Mot [1] theoretically predicted the possibility of the existence of similar substances in other pseudomonads. So they remain poorly studied. Studies of microcin-II-like bacteriocins $P$. aeruginosa are fundamentally new, because they have not been performed by other authors. We found that revealed substances are capable of penetrating through dialysis membrane with molecular weight cut-off (MWCO) $15 \mathrm{kDa}$ but don't penetrate through the membrane with MWCO 6-8 kDa. They don't influence own producer strains, lose activity after trypsin treatment $(1 \mathrm{mg} / \mathrm{mL})$ and their absorption peaks amount to $205-210 \mathrm{~nm}$, which is characteristic for peptide bond of proteins. We assumed that noted bacteriocins can be associated with S-type pyocins, produced by the same strains [15]. The relationship between different types of bacteriocins has been suggested by some authors [16], but not shown for pyocins. According to our previous results, S-type bacteriocins of $P$. aeruginosa are characterized by high activity against phytopathogenic $P$. syringae strains [17]. Presence of interaction between these two killer factors can determine methods of their use and activity increase of bacteriocins with antiphytopathogenic properties. That is why the aim of this work was to test possibility of interaction between S-type pyocins and microcinII-like bacteriocins in $P$. aeruginosa.

Materials and methods. The objects of investigation were $P$. aeruginosa strains - UCM B-9, UCM B-330, UCM B-332, UCM B-333, UCM B-335, maintained in Ukrainian collection of microorganisms (UCM, Zabolotny Institute of Microbiology and Virology, National Academy of Sciences of Ukraine). These strains of microorganisms are producers of highly active bacteriocins, corresponding data were published previously [18].

To obtain lysates of these $P$. aeruginosa strains, nalidixic acid was added to suspension of producer strains in the logarithmic growth phase (final concentration $100 \mu \mathrm{g} / \mathrm{ml}$ ). After further incubation for $3 \mathrm{~h}$, the induction was stopped by the addition of chloroform. The lysates were purified from bacterial detritus by low-speed centrifugation at $4.000 \mathrm{~g}$ for $30 \mathrm{~min}$. The obtained supernatants were aseptically removed and stored in closed containers at $4-6{ }^{\circ} \mathrm{C}$. Chloroform was used as a preserving agent [19].
Concentration of bacteriocins was conducted by $70 \%$ ammonium sulphate precipitation during 1 day at $4{ }^{\circ} \mathrm{C}$. The sediment was obtained at $30.000 \mathrm{~g}$ and $4{ }^{\circ} \mathrm{C}$ for $30 \mathrm{~min}$ and resuspended in $2 \mathrm{~mL}$ of $20 \mathrm{mM}$ Tris-HCl buffer (pH 7.5). The samples were dialyzed through dialysis membrane (MWCO $15 \mathrm{kDa}$ ) against $50 \mathrm{~mL}$ of $20 \mathrm{mM}$ Tris- $\mathrm{HCl}$ buffer for 1 day at $4{ }^{\circ} \mathrm{C}$ with a single replacement of dialysis buffer. Purification from insoluble admixture was carried out by low centrifugation at $4.000 \mathrm{~g}$ for 30 minutes [11].

Bacteriocins were separated by ion-exchange chromatography. For this purpose column (24× $245 \mathrm{~mm}$ ) was filled with regenerated DEAEcellulose and equilibrated with $500 \mathrm{~mL}$ of $20 \mathrm{mM}$ Tris-HCl buffer (pH 7.5). $10 \mathrm{ml}$ of bacteriocin sample was applied to this column, flushed with $200 \mathrm{~mL}$ of $20 \mathrm{mM}$ Tris-HCl buffer. Then step-bystep elution was conducted with $300 \mathrm{~mL}$ of 0 $0.3 \mathrm{M} \mathrm{NaCl}$ in $20 \mathrm{mM}$ Tris-HCl buffer. Eluates $(10 \mathrm{~mL})$ were collected into separate sterile tubes and kept at $4{ }^{\circ} \mathrm{C}$ with chloroform as a preserving agent.

For repeated bacteriocin separation we used gel filtration. In this case column $(5 \times 430 \mathrm{~mm})$ was filled with Sephadex G-75, equilibrated with $100 \mathrm{~mL}$ of $20 \mathrm{mM}$ Tris- $\mathrm{HCl}$ buffer (pH 7.5) with $0.15 \mathrm{M} \mathrm{NaCl} .1 \mathrm{ml}$ of bacteriocin sample was applied to this column; elution was conducted with $100 \mathrm{~mL}$ of previously mentioned buffer. Eluates $(3 \mathrm{~mL})$ were sampled in separate sterile tubes and stored at $4{ }^{\circ} \mathrm{C}$. Chloroform was used as a preserving agent [20].

In both methods protein concentration in obtained fractions was determined by absorbance measurement at $280 \mathrm{~nm}$ in comparison with $20 \mathrm{mM}$ Tris-HCl using SF-26. Protein content indices were determined by Bradford method [21].

For bacteriocin separation by ultracentrifugation according to Bradley [22] $12 \mathrm{~mL}$ of lysates were sampled and centrifuged at $215.000 \mathrm{~g}$ for 1 hour. At these parameters S-type pyocins pass into supernatants, marked as bacteriocin mixture. Obtained supernatants were precipitated repeatedly at $215.000 \mathrm{~g}$ for 4 hours. Then supernatants were selected separately, sediments were resuspended in $0.2 \mathrm{~mL}$ of TE buffer.

Antimicrobial activity at all separation stages was tested by "two-layer agar" method [19]. Quantitative indices of lysate activities were determined by double serial dilutions method, substance activity was estimated according to the maximal dilution able to cause formation of lysis 
zone. The obtained results were counted for $1 \mathrm{ml}$ of studied lysate and expressed in activity units $\mathrm{AU} / \mathrm{mL}$ or for convenience in $\times 10^{3} \mathrm{AU} / \mathrm{mL}$. P. aeruginosa UCM B-3 and UCM B-10 were used as indicator cultures [18].

SDS-PAGE of $P$. aeruginosa bacteriocin proteins was conducted according to the Laemmli method [23] in $10 \%$ Tris-Glycine SDS-PAGE gel, $100 \mathrm{~mA}, 2 \mathrm{~h}$, using as markers PageRuler Plus Prestained Protein Ladder, 10-250 kDa (Thermo Scientific). The data were processed using the TotalLab Quant software (v 2.0).

Results. The induction of $P$. aeruginosa UCM B-333 different type bacteriocins including microcin-II-like bacteriocins (M-II-LB) was conducted according to our optimized method, described previously [19]. Since this method was effective to obtain colicin-like S-type bacteriocins in high concentration, we decided to use it in these experiments. So, activity of $P$. aeruginosa
UCM B-333 induced lysates was $2.9 \times 10^{6} \mathrm{AU} / \mathrm{mL}$ (Table 1).

Concentration of killer factors was carried out by ammonium sulphate precipitation, which was added to $70 \%$ saturation. Bacteriocin activity in obtained precipitate increased by 9 times, protein content was equal to $3.7 \mathrm{mg} / \mathrm{mL}$. Desalinization of concentrated lysates and insoluble components elimination was realized by dialysis with further low-speed centrifugation. The application of mentioned methods partially decreased samples specific activity to $5.5 \times 10^{6} \mathrm{AU} / \mathrm{mg}$.

As it was shown previously, investigated $P$. aeruginosa strain is characterized by bacteriocin production multiplicity [18]. That is why for killer factor separation and to obtain purified M-II-LB fraction we applied ion-exchange chromatography with DEAE-cellulose. It was determined that available in lysates bacteriocins eluted simultaneously (Fig. 1).

\section{Table 1}

Stages of $P$. aeruginosa UCM B-333 pyocins purification

\begin{tabular}{|l|c|c|c|}
\hline Sample & $\mathrm{A}, \times 10^{3} \mathrm{AU} / \mathrm{mL}$ & $\mathrm{C}, \mathrm{mg} / \mathrm{mL}$ & $\mathrm{A}_{\mathrm{sp}} \times 10^{3} \mathrm{AU} / \mathrm{mg}$ \\
\hline Induced lysate & 2880 & 0.3 & 9600 \\
\hline Precipitate $70 \%\left(\mathrm{NH}_{4}\right)_{2} \mathrm{SO}_{4}$ & 25600 & 3.7 & 6919 \\
\hline Dialysate & 11520 & 2.1 & 5486 \\
\hline DEAE-cellulose $4^{\text {th }}$ fraction & 55 & 0.86 & 64 \\
\hline Sephadex $\mathrm{G}-755^{\text {th }}$ fraction & 8 & 0.23 & 35 \\
\hline
\end{tabular}

Legend: A - substance activity, $\mathrm{C}$ - protein concentration, $\mathrm{A}_{\mathrm{sp}}-$ specific activity.

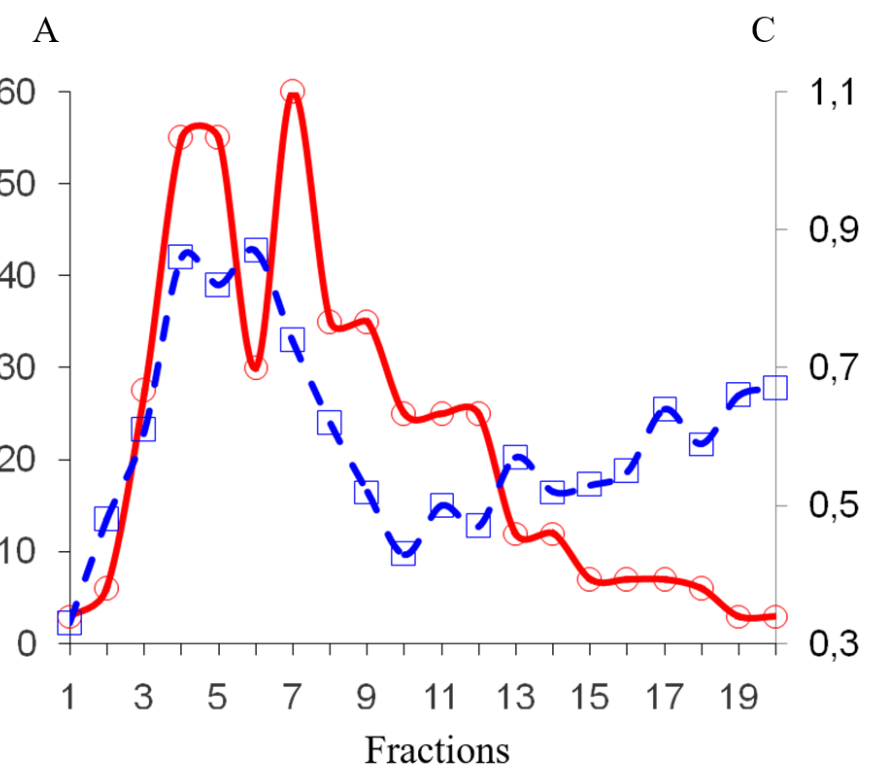

F i g. 1. Elution profile of $P$. aeruginosa UCM B-333 pyocins obtained by ion-exchange chromatography with DEAE-cellulose: A - activity, $\times 10^{3} \mathrm{AU} / \mathrm{mL}$; $\mathrm{C}$ - protein concentration, $\mathrm{mg} / \mathrm{mL}$ 
Peaks of activity indices were revealed in adjacent fractions 4.5 and 7 and were equal to $5.5 \times 10^{4}$ and $6 \times 10^{4} \mathrm{AU} / \mathrm{mL}$, respectively. Activity of substances in the $6^{\text {th }}$ fraction was twice lower $3.0 \times 10^{4} \mathrm{AU} / \mathrm{mL}$. But $4^{\text {th }}$ and $6^{\text {th }}$ fractions had the highest protein concentrations. Increased activity indices were also observed in following fractions, but they were characterized by low protein content. Thus, discordance in peaks of activity and protein concentration, expanded fraction profile indicated that these fractions contained unseparated substances of the same type.

To determine the belonging of obtained bacteriocins to certain subtype, SDS-PAGE was conducted (Fig. 2A). For this purpose we used substances from the $4^{\text {th }}$ fraction, which had the highest activity indices and the highest protein concentration simultaneously. After electrophoretic separation two protein bands with molecular weight near 58 and 9 кDa were revealed.

As we showed previously, genome of investigated strain contained genes of bacteriocin subtype S5, and their expression increased considerably under influence of nalidixic acid. According to Ling et al molecular weight of $\mathrm{S} 5$ pyocin is equal to $57.6 \mathrm{kDa}[5,24]$. In other our studies it was revealed that molecular weight of M-II-LB was equal to $9 \mathrm{kDa}$. So obtained fraction contained S5 pyocins and M-II-LB of P. aeruginosa.

To separate noted killer factors, substances from the $4^{\text {th }}$ fraction were subjected to gel filtration through Sephadex G-75 (Fig. 3). The results of this method revealed maximal protein concentration $-0.23 \mu \mathrm{g} / \mathrm{mL}$ in the $5^{\text {th }}$ fraction. Activity indices of this fraction were the highest $-8 \times 10^{3} \mathrm{AU} / \mathrm{mL}$. Other activity peaks or protein concentration maximum were not determined in neighbouring fractions. So it was suggested that gel filtration succeeded in separation of P. aeruginosa killer factors. Taking into account the difference between molecular weights of S5 pyocins and M-II-LB, obtained fraction must contain substances with lower molecular weight or M-II-LB. To confirm this assumption the secondary SDS-PAGE was conducted (Fig. 2B). After electrophoretic separation a single protein band with molecular weight near $9 \mathrm{kDa}$, which is typical for $P$. aeruginosa M-II-LB, was revealed in the $5^{\text {th }}$ fraction.

Thus isolation of purified M-II-LB from concentrated pyocin mixture of $P$. aeruginosa $\mathrm{UCM}$ B-333 is possible due to application of ionexchange chromatography with DEAE-cellulose and further gel filtration with Sephadex G-75.

Other method which allows to separate substances with different molecular weight is ultracentrifugation. In this case M-II-LB isolation was conducted from some $P$. aeruginosa strains. Bradley showed that ultracentrifugation at $215.000 \mathrm{~g}$ for 1 hour didn't precipitate colicin-like bacteriocins. We used centrifugation under noted parameters for purification of S-type pyocins and M-II-LB from high-molecular killer factors and admixture, possible present in composition of initial lysates. Obtained supernatants were signed as mixture (Table 2). Activity of supernatants from different strains was approximately the same and was equal to $12.8-51.2 \times 10^{3} \mathrm{AU} / \mathrm{mL}$ against P. aeruginosa UCM B-3 and 51.2-204.8 $\times 10^{3}$ $\mathrm{AU} / \mathrm{mL}$ - against $P$. aeruginosa UCM B-10.

According to Bradley, application of repeated ultracentrifugation at $215.000 \mathrm{~g}$ for 4 hours creates conditions for precipitation of S-type pyocins. Increase multiplicity of bacteriocin activity in precipitates, relative to mixture activity (index n), was equal to $80-320$ against $P$. aeruginosa $\mathrm{UCM}$ B-3 and 40-80 - against $P$. aeruginosa UCM B-10. M-II-LB are characterized by 7 times lower molecular weight then in S-type pyocins. Therefore

\section{Table 2}

\section{Activity of $P$. aeruginosa bacteriocins against indicator cultures $P$. aeruginosa UCM B-3 and UCM B-10 before and after ultracentrifugation at $215000 \mathrm{~g}$ for 4 hours}

\begin{tabular}{|l|c|c|c|c|c|c|c|c|c|c|}
\hline \multirow{2}{*}{ Strain } & \multicolumn{2}{|c|}{ Mixture } & \multicolumn{4}{c|}{ Precipitate } & \multicolumn{3}{c|}{ Supernatant } \\
\cline { 2 - 12 } & \multicolumn{2}{|c|}{ B-3 } & B-10 & \multicolumn{2}{|c|}{ B-3 } & \multicolumn{2}{c|}{ B-10 } & \multicolumn{2}{c|}{ B-3 } & \multicolumn{2}{c|}{ B-10 } \\
\cline { 2 - 12 } & \multicolumn{2}{|c|}{$\mathrm{A}$} & $\mathrm{A}$ & $\mathrm{n}$ & $\mathrm{A}$ & $\mathrm{n}$ & $\mathrm{A}$ & $\mathrm{n}$ & $\mathrm{A}$ & $\mathrm{n}$ \\
\hline B-9 & 12.8 & 102.4 & 1024 & +80 & 8192 & +80 & 25.6 & +2 & 102.4 & 0 \\
\hline B-330 & 51.2 & 204.8 & 8192 & +160 & 8192 & +40 & 102.4 & +2 & 409.6 & +2 \\
\hline B-332 & 25.6 & 102.4 & 8192 & +160 & 8192 & +80 & 102.4 & +2 & 102.4 & 0 \\
\hline B-333 & 25.6 & 102.4 & 8192 & +320 & 8192 & +80 & 51.2 & +2 & 204.8 & +2 \\
\hline B-335 & 12.8 & 51.2 & 1024 & +80 & 4096 & +80 & 25.6 & +2 & 102.4 & +2 \\
\hline
\end{tabular}

Legend: A - killer activity, $\times 10^{3} \mathrm{AU} / \mathrm{mL} ; \mathrm{n}-$ increase multiplicity of bacteriocin activity after ultracentrifugation relative to their activity in mixture composition. 
under used ultracentrifugation conditions these substances can't be precipitated and remain in supernatants. Also it was noted twice increase of supernatant activity indices against both indicator cultures $(n=2)$. Thus use of ultracentrifugation made possible not only to separate S-type pyocins and M-II-LB, but also to increase their activity indices.
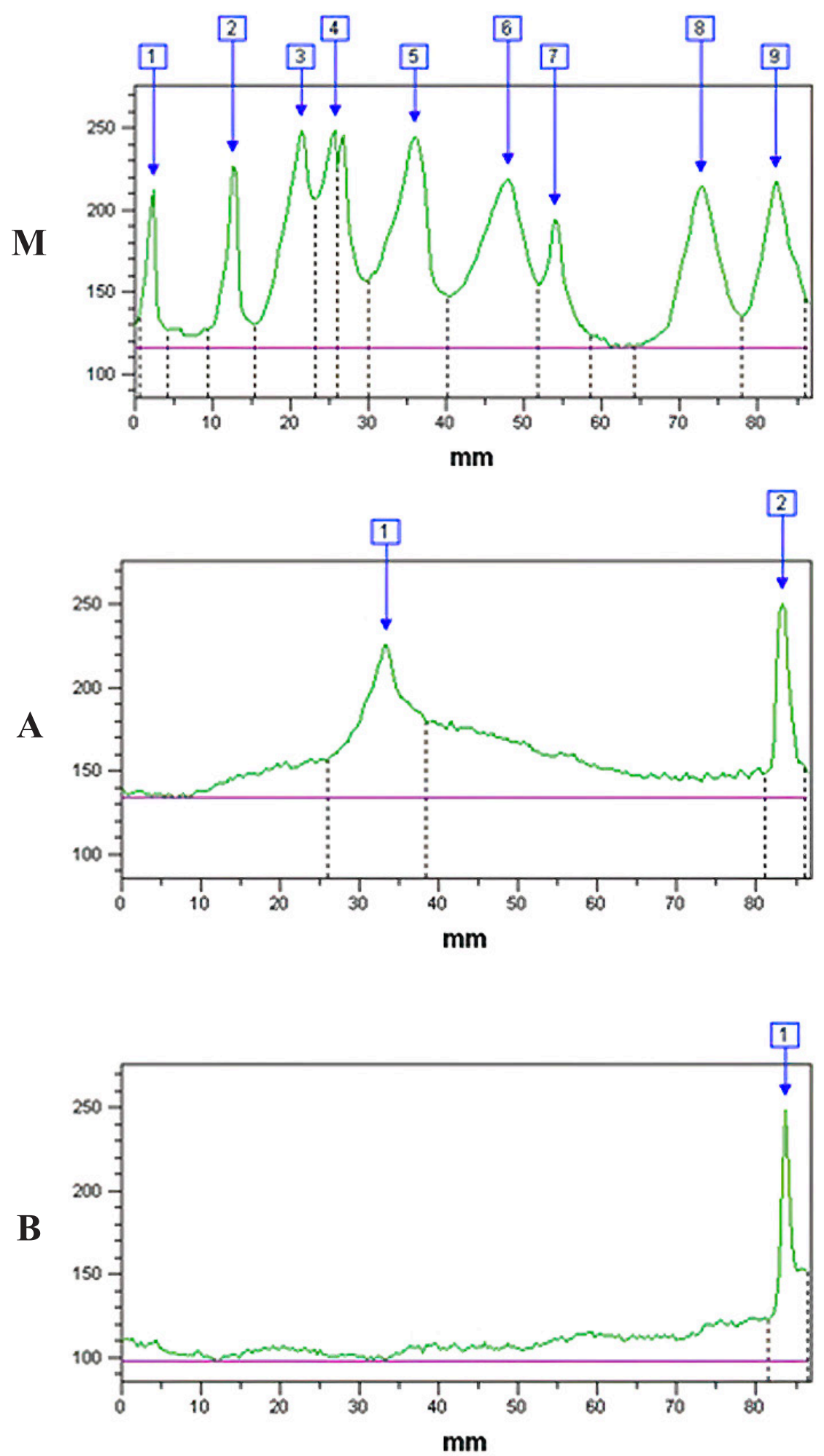

F i g. 2. Densitograms of P. aeruginosa bacteriocins contained in the $4^{\text {th }}$ fraction (A, peaks 1 and 2) after ion-exchange chromatography with DEAE-cellulose and in the $5^{\text {th }}$ fraction $(B$, peak 1$)$ after gel filtration through Sephadex G-75: M - molecular weight markers (PageRuler Plus Prestained

Protein Ladder, 10-250 kDa (Thermo Scientific): 1 - 250 kDa, 2 - 130 kDa, 3 - 100 kDa, 4 - $70 \mathrm{kDa}, 5$ - $55 \mathrm{kDa}, 6$ - $35 \mathrm{kDa}, 7$ - $25 \mathrm{kDa}, 8$ - $15 \mathrm{kDa}, 9$ - $10 \mathrm{kDa}$ 


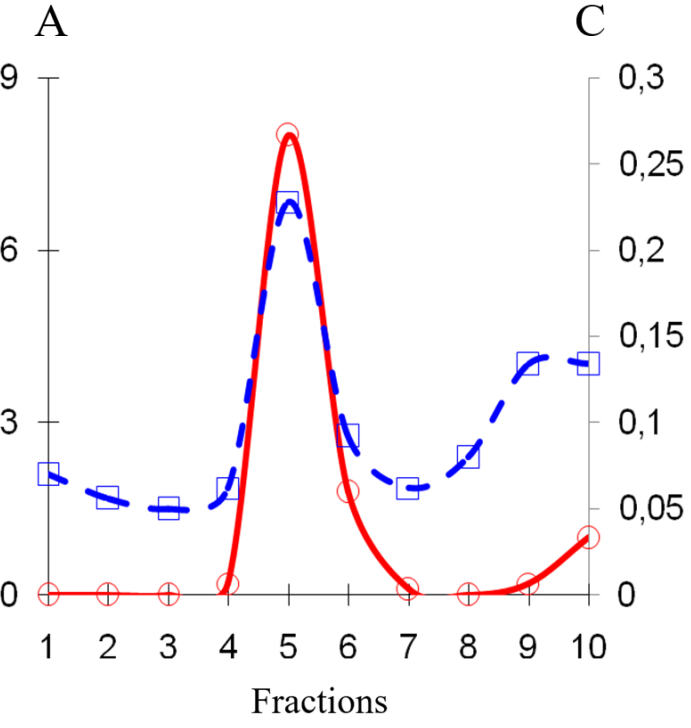

F i g. 3. Elution profile of $P$. aeruginosa UCM B-333 pyocins obtained by gel filtration through Sephadex G-75: A - activity, $\times 10^{3} \mathrm{AU} /$ $\mathrm{mL} ; \mathrm{C}$ - protein concentration, $\mathrm{mg} / \mathrm{mL}$
To estimate efficiency of this method application for increase of bacteriocin activity, indices of obtained precipitates and supernatants were determined during a period of their storage. In 14 days after ultracentrifugation supernatant activities decreased approximately by $4-16$ times, and for precipitates - by 80-640 times as compared with indices at the moment of their isolation (Table 3).

Under further observation detected tendency continued. So, in 90 days it was observed decrease in supernatants activities by $8-32$ times, and for precipitates - by 320-1280 times according to their initial parameters (Table 4). But on the other hand, killer activity indices of bacteriocin mixture, which contained the same but unseparated killer factors, didn't decrease or decreased minimally by 2 times against indicator culture $P$. aeruginosa UCM B-3 and by 8 times against UCM B- 10 .

This fact indicated that application of noted method for increase of bacteriocin activity has short-term result. During further storage of killer factors their activity decreased substantially.

Table 3

Activity of $P$. aeruginosa bacteriocins contained in unseparated and separated by ultracentrifugation samples against indicator cultures $P$. aeruginosa $\mathrm{UCM}$ B-3 and UCM B-10 after storage during 14 days

\begin{tabular}{|l|c|c|c|c|c|c|c|c|c|c|c|c|}
\hline \multirow{3}{*}{ Strain } & \multicolumn{4}{|c|}{14 days mixture } & \multicolumn{4}{c|}{ 14 days precipitate } & \multicolumn{3}{c|}{ 14 days supernatant } \\
\cline { 2 - 16 } & \multicolumn{2}{|c|}{$\mathrm{B}-3$} & \multicolumn{2}{|c|}{ B-10 } & \multicolumn{2}{c|}{ B-3 } & \multicolumn{2}{c|}{ B-10 } & \multicolumn{3}{c|}{ B-3 } & \multicolumn{2}{c|}{ B-10 } \\
\cline { 2 - 15 } & $\mathrm{A}$ & $\mathrm{n}$ & $\mathrm{A}$ & $\mathrm{n}$ & $\mathrm{A}$ & $\mathrm{n}$ & $\mathrm{A}$ & $\mathrm{n}$ & $\mathrm{A}$ & $\mathrm{n}$ & $\mathrm{A}$ & $\mathrm{n}$ \\
\hline B-9 & 12.8 & 0 & 51.2 & -2 & 12.8 & -80 & 51.2 & -160 & 6.4 & -4 & 6.4 & -16 \\
\hline B-330 & 25.6 & -2 & 102.4 & -2 & 12.8 & -640 & 51.2 & -160 & 25.6 & -4 & 25.6 & -16 \\
\hline B-332 & 25.6 & 0 & 102.4 & 0 & 51.2 & -160 & 51.2 & -160 & 51.2 & -2 & 25.6 & -4 \\
\hline B-333 & 25.6 & 0 & 102.4 & 0 & 51.2 & -160 & 51.2 & -160 & 12.8 & -4 & 12.8 & -16 \\
\hline B-335 & 12.8 & 0 & 25.6 & -2 & 12.8 & -80 & 12.8 & -320 & 12.8 & -2 & 51.2 & -2 \\
\hline
\end{tabular}

Legend: A - killer activity, $\times 10^{3} \mathrm{AU} / \mathrm{mL} ; \mathrm{n}-$ decrease multiplicity of bacteriocin activity after storage during 14 days relative to their activity in composition of corresponding initial samples.

Table 4

Activity of $P$. aeruginosa bacteriocins contained in unseparated and separated by ultracentrifugation samples against indicator cultures $P$. aeruginosa $\mathrm{UCM}$ B-3 and UCM B-10 after storage during 90 days

\begin{tabular}{|c|c|c|c|c|c|c|c|c|c|c|c|c|}
\hline \multirow{3}{*}{ Strain } & \multicolumn{4}{|c|}{90 days mixture } & \multicolumn{4}{|c|}{90 days precipitate } & \multicolumn{4}{|c|}{90 days supernatant } \\
\hline & \multicolumn{2}{|c|}{ B-3 } & \multicolumn{2}{|c|}{ B-10 } & \multicolumn{2}{|c|}{ B-3 } & \multicolumn{2}{|c|}{ B-10 } & \multicolumn{2}{|c|}{ B-3 } & \multicolumn{2}{|c|}{ B-10 } \\
\hline & $\mathrm{A}$ & $\mathrm{n}$ & $\mathrm{A}$ & $\mathrm{n}$ & $\mathrm{A}$ & $\mathrm{n}$ & $\mathrm{A}$ & $\mathrm{n}$ & $\mathrm{A}$ & $\mathrm{n}$ & $\mathrm{A}$ & $\mathrm{n}$ \\
\hline B-9 & 6.4 & -2 & 12.8 & -8 & 1.6 & -640 & 6.4 & -1280 & 1.6 & -16 & 3.2 & -32 \\
\hline B-330 & 25.6 & -2 & 51.2 & -4 & 6.4 & -1280 & 12.8 & -640 & 12.8 & -8 & 25.6 & -16 \\
\hline B-332 & 25.6 & 0 & 25.6 & -4 & 6.4 & -1280 & 25.6 & -320 & 12.8 & -8 & 12.8 & -8 \\
\hline B-333 & 25.6 & 0 & 25.6 & -4 & 12.8 & -640 & 25.6 & -320 & 3.2 & -16 & 6.4 & -32 \\
\hline B-335 & 6.4 & -2 & 12.8 & -4 & 1.6 & -640 & 3.2 & -1280 & 3.2 & -8 & 25.6 & -4 \\
\hline
\end{tabular}

Legend: A - killer activity, $\times 10^{3} \mathrm{AU} / \mathrm{mL} ; \mathrm{n}-$ decrease multiplicity of bacteriocin activity after storage during 90 days relative to their activity in composition of corresponding initial samples. 
Thus ultracentrifugation allows to separate S-type pyocins and M-II-LB, but application of this method for their activities increase is inexpedient.

Discussion. In our previous studies it was shown that M-II-LB are able to penetrate through a semipermeable membrane with MWCO $15 \mathrm{kDa}$ [11]. We took advantage of revealed ability for their isolation separately from other killer factors. That is why, in this work, to prevent the loss of low-molecular bacteriocins, lysate purification was conducted using membrane with MWCO $3 \mathrm{kDa}$. As a result, bacteriocin mixture applied to column with DEAE-cellulose contained both S-type pyocins and M-II-LB.

It is known that molecules of $\mathrm{S} 1$ pyocins are characterized by weak positive charge; therefore they don't fix with DEAE-cellulose and flush by pure buffer during elution. We didn't select these fractions; therefore availability of this type pyocins weren't confirmed. Properties of our isolated M-II-LB hadn't been studied. But their absorption peak was in near ultraviolet range at wave length 205-210 nm. It indicates the absence of tyrosine, tryptophan and in less measure histidine and phenylalanine [15]. Similar properties are characteristic for microcins B17, C7 and H47. Their total surface charge is equal to zero or weak positive. DEAE-cellulose is one of anion-exchange sorbates, which binds substances with negative surface charge. But during elution of S5 pyocins and M-II-LB mixture through noted carrier, these substances remain bound with each other. Adduced facts can indicate availability of weak electrostatic interaction between these killer factors. It is known that substance separation by gel filtration, ultracentrifugation and dialysis is not connected with their molecule charge, and based exclusively on differences in size and molecular weight. The results described in this work and obtained in previous studies indicated that application of noted methods allows to separate S-type pyocins with higher molecular weight from low molecular weight M-II-LB. If mentioned killer factors interact with each other in the way, different from electrostatic one, their separation will be limited or impossible.

It was shown in the study that the use of ultracentrifugation in most cases led to increase of bacteriocin activity in precipitates by 80 160 times. But their volume comparing with volume of bacteriocin mixture decreased only by 60 times. So we observed additional, not connected with decrease of sample volume, activity increase of S-type pyocins by 1.5-2.5 times. However supernatants volume in comparison with volume of bacteriocin mixture practically didn't change. As the result of S-type bacteriocin precipitation, it could be expected that supernatant activity will decrease. But we observed inverse relationship - double increase of their activity indices. Thus application of ultracentrifugation resulted in the same increase of S-type bacteriocins and M-II-LB. The revealed dependence additionally confirmed previous assumption about interaction of these killer factors with each other. Their separation probably release lysis domain and improve interaction of each type bacteriocins with receptors of sensitive cells.

Testing of separated by ultracentrifugation precipitates and supernatants showed sharp decrease of their activity indices after 14 days of storage. Detected dependence continued farther during 90 days of observation but wasn't so evident. It should be noted that comparing with intensive activity fall of S-type pyocins in precipitates, indices of M-II-LB in supernatants decreased considerably less. At the same time activity of mixture contained unseparated killer factors of both types didn't practically change. So, S-type pyocins and M-II-LB of $P$. aeruginosa interact with each other, that ensures their stabilization and protects again destruction.

Comparing described methods of purified M-IILB isolation it should be noted that application of ion-exchange chromatography with DEAEcellulose with following gel filtration through Sephadex G-75 so as ultracentrifugation enables to attain assigned task. But they are technologically complicated; require long-term stages of sample preparation. Application of ultracentrifugation is inexpedient, since it leads to decrease of bacteriocin activity under further storage. In contrast to noted approaches, our previously described method of dialysis for $P$. aeruginosa concentrated lysates through a semipermeable membrane with MWCO $15 \mathrm{kDa}$ [15] can be considered not only effective in the same measure but also more accessible to wide application.

Conclusions. S-type pyocins and microcinII-like bacteriocins of $P$. aeruginosa interact with each other, that ensures their stabilization and protects again destruction. Application of methods that cause separation of these killer factors is inexpedient, since it results into considerable decrease of bacteriocin activity indices. 


\section{ВЗАСМОДІЯ ПІОЦИНІВ S-ТИПУ I МІКРОЦИН-ІІ-ПОДІБНИХ БАКТЕРІОЦИНІВ PSEUDOMONAS AERUGINOSA}

\section{О.Б. Балко}

\begin{abstract}
Інститут мікробіології і вірусологї ім. Д.К. Заболотного НАН Украӥни, вул. Академіка Заболотного, 154, Київ, 03143, Україна
\end{abstract}

Резюме

За результатами наших попередніх досліджень було показано, що бактеріоцини S-типу Pseudomonas aeruginosa характеризуються високою активністю щодо фітопатогенних штамів Pseudomonas syringae. Окрім даних піоцинів, штами-продуценти здатні виділяти мікроцин-IIподібні бактеріоцини. Наявність взаємодії між цими кілерними факторами може визначати методи їх використання і підвищення активності бактеріоцинів з антифітопатогенними властивостями. Метою роботи було перевірити можливість взаємодії піоцинів S-типу і коліцин-ІІ-подібних бактеріоцинів $P$. aeruginosa. Методи. Об'єктом дослідження були піоцини, синтезовані 6 штамами $P$. aeruginosa . Кілерні фактори у складі індукованих лізатів концентрували висолюванням 70\%-ним сульфатом амонію, діалізували через діалізну мембрану з порогом відсічення 3,5 кДа, після чого для їх розділення використовували іонообмінну хроматографію на ДЕАЕцелюлозі, гель-фільтрацію на сефадексі G-75 та ультрацентрифугування при $215.000 \mathrm{~g}$ протягом 1 i 4 год. В отриманих фракціях визначали вміст білка та антимікробну активність. Візуалізацію білків у складі активних фракцій проводили ме-

1. Ghequire MGK, De Mot R. Ribosomally encoded antibacterial proteins and peptides from Pseudomonas. FEMS Microbiol Rev. 2014; 38:3852338568 .

2. Ghequire MGK, Öztürk B, De Mot R. Lectin-Like Bacteriocins. Front Microbiol. 2018; 9:2706. doi: 10.3389/fmicb.2018

3. Scholl D. Phage tail-like bacteriocins. Ann Rev Virol. 2017; 4:453-467. doi: 10.1146/annurev-virology-101416-041632

4. Ghequire MG, De MotR. The tailocin tale: peeling off phage tails. Trends Microbiol. 2015; 23:587-590. doi: 10.1016/j.tim.2015.07.011 тодом електрофорезу за Laemmli. Результати. При використанні іонообмінної хроматографії на ДЕАЕ-целюлозі елюція наявних у складі лізатів бактеріоцинів відбувалась одночасно. Найвищі показники активності і концентрації білка виявлялись у фракції 4, яка містила дві білкові полоси 3 молекулярними масами близько 58 і 9 кДа, характерні S5 піоцинам і мікроцин-ІІ-подібним бактеріоцинам P. aeruginosa. Подальше гельфільтрування відібраних фракцій через сефадекс G-75 дозволило розділити вказані кілерні фактори і отримати очищену фракцію, яка містила виключно мікроцин-ІІ-подібні піоцини. Використання ультрацентрифугування протягом 1 год не осаджувало досліджувані бактеріоцини, тоді як протягом 4 год - призводило до їх розділення. При цьому спостерігалось двократне підвищення показників активності піоцинів S-типу у складі осаду, а мікроцин-ІІ-подібних кілерних факторів в супернатантах. Однак досягнуте концентрування характеризувалось лише короткостроковим ефектом, оскільки вже через 14 діб активність супернатантів знижувалась у 4-16 разів, а осадів - у 80-640 разів. В подальшому виявлена тенденція до зниження активності зберігалась. Висновки. Піоцини S-типу і мікроцин-ІІ-подібні бактеріоцини $P$. aeruginosa взаємодіють між собою, що забезпечує їх стабілізацію і захищає від руйнування. Використання методів, які спричиняють розділення даних кілерних факторів, $є$ недоцільним, оскільки призводять до значного зниження показників активності бактеріоцинів.

Ключові слова: мікроцин-ІІ-подібні бактеріоцини, піоцини S-типу, Pseudomonas aeruginosa, взаємодія.

5. Behrens HM, Lowe ED, Gault J, Housden NG, Kaminska R, Weber TM, Thompson CMA, Mislin GLA, Schalk IJ, Walker D, Robinson CV, Kleanthous C. Pyocin S5 Import into Pseudomonas aeruginosa Reveals a Generic Mode of Bacteriocin Transport. MBio. 2020; 11(2) e0323019; DOI: 10.1128/mBio.03230-19

6. Sharp C, Bray J, Housden NG, Maiden MCJ, Kleanthous C. Diversity and distribution of nuclease bacteriocins in bacterial genomes revealed using Hidden Markov Models. PLoS Comput Biol. 2017; 13:e1005652. doi: 10.1371/journal. pcbi. 1005652 
7. Mojesky AA, Remold SK. Spatial structure maintains diversity of pyocin inhibition in household Pseudomonas aeruginosa. Proc R Soc B. 2020; 287: 20201706

8. Balko OI, Balko OB, Avdeeva LV. Bacteriocins of some groups of Gram-negative bacteria. Mikrobiol Z. 2020; 82(3):71-84. doi: https://doi. org/10.15407/microbiolj82.03.071

9. Snopkova K, Dufkova K, Klimesova P, Vanerkova M, Ruzicka F, Hola V. Prevalence of bacteriocins and their co-association with virulence factors within Pseudomonas aeruginosa catheter isolates. International Journal of Medical Microbiology. 2020; 310(8):151454.

10. Michel-Briand Y, Baysse C. The pyocins of Pseudomonas aeruginosa. Biochimie. 2002; 84(5):499-510.

11. Balko OB. Low molecular weight Pseudomonas aeruginosa bacteriocins. Mikrobiol Z. 2019; 81(6):97-109. doi: https://doi.org/10.15407/microbiolj81.06.097

12. Baquero F, Lanza VF, Baquero M-R, Campo R, Bravo-Vázquez DA. Microcins in Enterobacteriaceae: Peptide Antimicrobials in the Eco-Active Intestinal Chemosphere. Front Microbiol. 2019; 10:2261. doi: 10.3389/fmicb.2019.02261

13. Massip C, Oswald E. Siderophore-Microcins in Escherichia coli: Determinants of Digestive Colonization, the First Step Toward Virulence. Front Cell Infect Microbiol. 10:381. doi: 10.3389/ fcimb.2020.00381

14. Metelev M, Serebryakova M, Ghilarov D, Zhao Y, Severinov K. Structure of microcin B-like compounds produced by Pseudomonas syringae and species specificity of their antibacterial action. J Bacteriol. 2013; 195:4129-4137. doi: 10.1128/ JB.00665-13

15. Balko OI, Balko OB, Avdeeva LV. Thermoactivation of Pseudomonas aeruginosa bacteriocins. Mikrobiol Z. 2019; 81(5):85-97. doi: https://doi. org/10.15407/microbiolj81.05.085
16. Hockett KL, Renner T, Baltrus DA. Independent co-option of a tailed bacteriophage into a killing complex in Pseudomonas. mBio. 2015; 6:e0452. doi: 10.1128/mBio.00452-15

17. Balko OI, Yaroshenko LV, Balko OB, Pasichnyk LA, Avdeeva LV. [Pseudomonas aeruginosa bacteriocin activity against Pseudomonas syringae phytopathogenic strains]. Microbiology and biotechnology. 2017; 2:51-60. Ukrainian. DOI: 10.18524/2307-4663.2017.2(38).105017

18. Balko AB, Avdeeva LV. [Screening of producers of bacteriocin-like substances active against Pseudomonas aeruginosa]. Mikrobiol Z. 2012; 74(2):8-13. Russian.

19. Balko AB, Vidasov VV, Avdeeva LV. [Optimization of conditions of Pseudomonas aeruginosa bacteriocin induction]. Microbiol Z. 2013; 75(1):79-85. Russian.

20. Ito S, Kageyama M, Egami F. Isolation and characterization of pyocins from several trains of Pseudomonas aeruginosa J Gen Appl Microbiol. 1970; 16(3):205-214.

21. Kruger NJ. The Bradford Method for Protein Quantitation. In: Walker JM, editor. Basic Protein and Peptide Protocols. Methods in Molecular Biology, vol. 32. Humana Press. 1994:9-15. https://doi.org/10.1385/0-89603-268-X:9

22. Bradley DE. Ultrastructure of bacteriophage and bacteriocins. Bacteriol Rev. 1967; 31(4):230314.

23. Laemmli UK. Cleavage of structural proteins during the assembly of the head of bacteriophage T. Nature. 1970; 227(5259):680-685.

24. Ling H, Saeidi N, Rasouliha BH, Chang MW. A predicted S-type pyocin shows a bactericidal activity against clinical Pseudomonas aeruginosa isolates through membrane damage. FEBS Letters. 2010 ; 584:3354-3358.

Received 7.02.2021 